\title{
PENGARUH METODE INKUIRI TERBIMBING TERHADAP KETERAMPILAN PROSES SAINS DAN HASIL BELAJAR BIOLOGI SISWA KELAS VIII DI SMPN 3 GUNUNGSARI TAHUN AJARAN 2013/2014
}

\author{
Nur Yasmin, Agus Ramdani, Afriana Azizah \\ Program Studi Pendidikan Biologi, Jurusan PMIPA, FKIP Universitas Mataram
}

\begin{abstract}
ABSTRAK: Melalui proses inkuiri dan belajar dengan melakukan (learning by doing), peserta didik dapat melatih keterampilan proses sains mereka sekaligus memperoleh pembelajaran yang bermakna. Berbagai penelitian telah menunjukkan bahwa belajar dengan melakukan (learning by doing) dan melalui proses inkuiri dapat meningkatkan hasil belajar peserta didik, termasuk hasil belajar kognitif dan ke-terampilan proses sains. Berdasarkan hasil observasi peneliti di sekolah, diketahui bahwa pembelajaran Biologi masih menekankan pada pembelajaran yang sifatnya konseptual, teoritis dan hafalan melalui buku serta masih berpusat pada guru (teacher-centered). Peserta didik tidak dibiasakan melakukan inkuiri ilmiah melalui eksperimen dan melatih keterampilan proses sains mereka. Akibatnya, hasil belajar mereka belum mencapai hasil yang memuaskan. Metode inkuiri terbimbing di-harapkan dapat mengatasi permasalahan ini. Oleh karena itu, tujuan dalam penelitian ini adalah untuk mengetahui pengaruh metode inkuiri terbimbing terhadap keterampilan proses sains dan hasil belajar Biologi peserta didik. Penelitian ini telah dilaksanakan di SMPN 3 Gunungsari dari bulan Januari sampai Maret 2014. Populasi dalam penelitian ini adalah seluruh peserta didik kelas VIII tahun ajaran 2013/2014 yang terbagi dalam 5 kelas, kelas VIII A - kelas VIII E. Sampel ditentukan melalui teknik simple random sampling dan diperoleh kelas VIII A sebagai kelas eksperimen dan kelas VIII C sebagai kelas kontrol. Desain penelitian ini menggunakan nonequivalent control group design. Instrumen yang digunakan untuk mengukur keterampilan proses sains dan hasil belajar Biologi adalah tes pilihan ganda yang sudah valid. Data berupa nilai hasil belajar dan keterampilan proses sains dianalisis menggunakan uji-t pada taraf signifikansi $5 \%$. Hasil penelitian menunjukkan:bahwa tidak terdapat perbedaan hasil belajar Biologi dan keterampilan proses sains yang signifikan pada kedua kelas. Dengan demikian dapat disimpulkan bahwa: metode inkuiri terbimbing memberikan pengaruh yang sama baiknya dengan metode ceramah bervariasi dan praktikum terhadap hasil belajar dan keterampilan proses sains peserta didik.
\end{abstract}

Kata kunci: $\quad$ Metode Inkuiri Terbimbing, Keterampilan Proses Sains, Hasil Belajar

ABSTRACT: Students are capable to improve their skills in scientific process and to get meaningful learning both by inquiry learning and learning by doing. Many researches reported that learning by doing and inquiry learning could improve student's achievements, including cognitive achievement and secientific process skills. It was observed that Biology learning at school still mainly emphasize on conceptual, theoritical, recitation learning through textbook and tend to be teacher centered. The students were unfamiliar to do scientific inquiry through experiment and train their scientific process skills. As a consequence, their learning achievement still unsatisfied. Guided inquiry method is expected can overcome this problem. Therefore, the aim of this research is to examine the effect of guided inquiry method on student's scientific process skills and Biology learning achievement. This research was conducted in SMPN 3 Gunungsari from January to March 2014. Population of this study were all students at grade VIII of academic year 2013/2014 which divided into five classes, VIII A VIII E. Samples were determined by simple random sampling technique and obtained VIII A as experimental class and VIII $\mathrm{C}$ as control class. Research design was nonequivalent control group design. Instrument to measure both student's scientific process skills and Biology learning achievement was a valid multiple choices test. Data of students's Biology learning achievement and scientific process skills were analyzed by using t-test formula at level of significant 5\%. Results showed that students's Biology learning achievement and scientific process skills in both classes were not significantly different. Therefore, it can be concluded that effectiveness of expository and experiment method is as good as guided inquiry method on students's Biology learning achievement and scientific process skills.

Key words: $\quad$ Guided Inquiry Method, Science Process Skills, Learning Achievement

\section{PENDAHULUAN}

Biologi merupakan salah satu mata pelajaran yang termasuk dalam rumpun mata pelajaran IPA atau Sains. Menurut (11), belajar dan pembelajaran IPA merupakan proses pembentukan kompetensi (competency based learning), bukan sekedar proses transfer pengetahuan oleh guru (knowledge based learning) kepada peserta didik. Pendekatan pem-belajaran IPA hendaknya tidak 
lagi terlalu berpusat pada pendidik (teacher centered) melainkan harus lebih berorientasi pada peserta didik (student centered). Perananan pendidik perlu bergeser dari menentukan apa yang harus dipelajari menjadi bagaimana menyediakan dan memperkaya pengalaman belajar peserta didik. Pengalaman belajar bagi peserta didik dapat diperoleh melalui serangkaian kegiatan mengeksplorasi lingkungan, melalui interaksi aktif dengan teman sejawat dan seluruh lingkungan belajarnya.

Pembelajaran IPA menekankan pada pengalaman langsung untuk mengembangkan kompetensi agar peserta didik mampu memahami alam sekitar melalui proses mencari tahu dan berbuat. Keterampilan mencari tahu atau berbuat tersebut dinamakan dengan keterampilan proses penyelidikan atau inquiry skills yang meliputi mengamati, mengukur, meng-golongkan, mengajukan pertanyaan, menyusun hipotesis, merencanakan eksperimen untuk menjawab pertanyaan, mengklasifikasikan, mengolah dan meng-analisis data, menerapkan ide pada situasi baru, menggunakan peralatan sederhana, serta mengkomunikasikan informasi melalui berbagai cara misalnya dengan gambar, lisan, tulisan, dan sebagainya (23).

Kecenderungan pembelajaran IPA pada masa kini adalah peserta didik hanya mempelajari IPA sebagai produk, meng-hafalkan konsep, teori, dan hukum. Keadaan ini diperparah oleh pembelajaran yang berorientasi pada tes/ujian. Akibatnya IPA sebagai proses, sikap, dan aplikasi tidak tersentuh dalam pembelajaran. Pembelajaran lebih bersifat teacher centered, guru hanya menyampaikan IPA sebagai produk dan peserta didik menghafal informasi faktual. Peserta didik hanya mempelajari IPA pada domain kognitif terendah. Peserta didik tidak dibiasakan untuk mengembangkan potensi berpikir-nya. Fakta di lapangan menunjukkan bahwa banyak peserta didik yang cenderung menjadi malas berpikir secara mandiri (23).

Melalui observasi dan wawancara dengan guru mata pelajaran IPA Biologi kelas VIII di sekolah, diketahui bahwa pembelajaran Biologi masih menekankan pada pembelajaran yang sifatnya konseptual, teoritis dan hafalan melalui buku serta masih cenderung berpusat pada guru. Peserta didik tidak dibiasakan melakukan inkuiri ilmiah melalui eksperimen dan melatih keterampilan proses sains mereka. Selain itu, dalam pembelajaran Biologi berbasis praktikum, peserta didik hanya dilatih menggunakan keterampilan proses sains dasar seperti mengamati dan melakukan pengukuran. Hasil belajar peserta didik, apabila dilihat dari rata-rata nilai akhir semester, belum menunjukkan hasil yang memuaskan.

Salah satu alternatif metode pembelajaran yang diharapkan dapat mengatasi permasalahan dalam pem-belajaran Biologi adalah metode inkuiri. Pembelajaran sains berbasis inkuiri mengajak peserta didik untuk membangun pengetahuan mengenai alam secara aktif (2). Inkuiri menggambarkan proses-proses yang dilakukan oleh para ilmuwan secara rutin dalam penelitian mereka, dan menyediakan suatu metode bagi peserta didik untuk mempelajari sains dari segi isi dan keterampilan (21). Melalui partisipasi dalam inkuri seperti ilmuwan, peserta didik belajar memunculkan pertanyaan, mengumpulkan data melalui pengamatan dan penyelidikan, memperoleh pengetahu-an sains, menggunakan pengetahuan tersebut dalam memahami dan menjelaskan data hasil pengamatan (4).

Menurut (11) terdapat lima fase/ langkah-langkah dalam metode inkuiri secara umum, yaitu: a) merumuskan pertanyaan; b) merumuskan hipotesis; c) mengumpulkan data; d) menguji hipotesis; dan e) menarik kesimpulan.

Beberapa ahli membagi metode inkuiri menjadi berbagai tipe atau tingkatan, yaitu: inkuiri konfirmasi, inkuiri terstruktur, inkuiri terbimbing, inkuiri individual, inkuiri terbuka, inkuiri autentik, inkuiri berpasangan, inkuiri bebas yang dimodifikasi (3) (5) (7) (9) (12) Pada intinya, perbedaan setiap tipe inkuiri terletak pada proporsi kebebasan peserta didik dan keterlibatan guru dalam setiap fasenya.

Guru perlu mengaktifkan peserta didik secara fisik maupun mental untuk membangun pemahamannya tentang alam semesta dan lingkungan sekitar dengan menggunakan keterampilan proses dalam pembelajaran sains di sekolah (11). Keterampilan proses sains adalah sejumlah keterampilan untuk mengkaji fenomena alam seperti yang dilakukan para ahli sains (ilmuwan), antara lain: melakukan pengamatan, klasifikasi, inferensi, merumuskan hipotesis, dan melakukan eksperimen (8).

Keterampilan proses sains dapat di-bagi menjadi keterampilan proses sains dasar dan keterampilan proses sains terpadu. Proses sains dasar dikatakan sebagai proses sains paling sederhana dan mungkin terlihat sebagai prosedur empiris atau analitis yang diturunkan dari praktikum sains dan mungkin saja biasa dilakukan oleh peserta didik dalam kehidupan mereka seharihari. Proses sains terpadu merupakan proses yang meng-gabungkan dua atau lebih proses sains dasar (2).

Proses sains dasar terdiri dari: a) mengamati, b) mengelompokkan, c) meng-ukur, d) berkomunikasi, e) menyimpulkan, f) meramalkan, g) mengestimasi, h) meng-hubungkan dengan ruang atau waktu, i) menggunakan angka-angka, dan j) meng-identifikasi variabel (2) (15). 
Proses sains terpadu terdiri dari: a) merumuskan hipotesis, b) mengontrol variabel, c) menyelidiki, d) mendefinisikan secara operasional, e) mengidentifikasi, membuat grafik, g) menafsirkan data, memperagakan, dan i) melakukan percobaan (15).

Berdasarkan pendapat-pendapat tersebut dapat terlihat bahwa dalam fase metode inkuiri mendukung keterampilan proses sains, sehingga melalui pembelajar-an menggunakan metode inkuiri dapat melatih keterampilan proses sains peserta didik. Selain itu, melalui proses penemuan sendiri fakta dan konsep yang sedang dipelajari, diharapkan hasil belajar peserta didik menjadi lebih baik. Menurut (16), hasil belajar adalah prestasi belajar peserta didik secara keseluruhan yang menjadi indikator kompetensi dasar dan derajat perubahan perilaku individu bersangkutan.

Metode yang diteliti dalam peneliti-an ini adalah metode inkuiri terbimbing. Menurut (7), inkuiri terbimbing yaitu pelaksanaan inkuiri yang dilakukan atas petunjuk dari guru. Dimulai dari guru mengajukan berbagai pertanyaan yang melacak dengan tujuan untuk mengarahkan peserta didik menuju ke titik kesimpulan yang diharapkan. Selanjutnya, peserta didik melakukan percobaan untuk membuktikan pendapat yang dikemukakan.

Penelitian yang relevan pernah di-lakukan antara lain oleh (14) menunjukkan bahwa metode inkuiri terbimbing dapat meningkatkan keterampilan proses sains mahasiswa program studi Pendidikan Fisika pada pokok bahasan fluida. Hasil penelitian yang dilakukan oleh (25) menunjukkan bahwa pembelajaran metode inkuiri terbimbing berbantuan multimedia dapat meningkatkan hasil belajar kognitif peserta didik dalam pembelajaran Fisika. Penelitian lainnya yang dilakukan oleh (1) mengenai pengaruh metode inkuiri terbimbing terhadap keterampilan proses sains menunjukkan bahwa peserta didik yang diajar menggunakan metode inkuiri terbimbing memiliki keterampilan proses sains yang lebih tinggi dibandingkan dengan metode konvensional dalam pem-belajaran Biologi pada pokok bahasan Sistem Peredaran Darah. Penelitian yang dilakukan oleh (14) menunjukkan bahwa pembelajaran dengan metode inkuiri terbimbing dapat meningkat kan pemahaman konsep peserta didik dalam pembelajaran Biologi.

Berdasarkan latar belakang tersebut, maka tujuan dalam penelitian ini adalah untuk mengetahui pengaruh metode inkuiri terbimbing terhadap keterampilan proses sain dan hasil belajar Biologi pada peserta didik kelas VIII di SMPN 3 Gunungsari tahun ajaran 2013/2014.

\section{METODE PENELITIAN}

Jenis penelitian ini adalah eksperimen semu (quasi experiment). Desain penelitian yang digunakan adalah non-equivalent control group design. Penelitian ini dilaksanakan di SMPN 3 Gunungsari terhadap peserta didik kelas VIII semester genap tahun ajaran 2013/ 2014. Populasi dalam penelitian ini adalah seluruh peserta didik kelas VIII yang terbagi dalam lima kelas, sampel ditentukan dengan teknik simple random sampling dan diperoleh kelas VIII A sebagai kelas eksperimen yang diberikan pembelajaran dengan metode inkuiri terbimbing dan kelas VIII C sebagai kelas kontrol yang diberikan pembelajaran dengan metode ceramah ber-variasi. Materi yang diajarkan dalam penelitian ini adalah Fotosintesis dan Gerak Tumbuhan.

Variabel bebas dalam penelitian ini adalah metode inkuiri terbimbing dan variabel terikatnya adalah keterampilan proses sains dan hasil belajar Biologi. Instrumen yang digunakan berupa tes pilihan ganda yang telah valid dan reliabel dengan rincian tes KPS sebanyak 26 soal dan tes hasil belajar sebanyak 30 soal. Analisis uji hipotesis menggunakan uji-t dengan bantuan program Microsoft Excel 2007.

Keterampilan proses sains dasar yang diteliti dalam penelitian ini yaitu meramalkan, mengukur, mengidentifikasi variabel, dan menyimpulkan. Keterampilan proses sains terpadu yang diteliti dalam penelitian ini yaitu merumuskan hipotesis, mengendalikan variabel, menafsirkan data, dan bereksperimen. Hasil belajar yang diteliti adalah hasil belajar pada ranah kognitif.

\section{HASIL DAN PEMBAHASAN}

\section{Hasil Belajar Kognitif}

Hasil post-test merupakan nilai rata-rata dari kedua materi yang diajarkan. Nilai rata-rata hasil belajar peserta didik di kelas eksperimen 63 dan di kelas kontrol 56. Visualisasi perbedaan ratarata di kedua kelas sampel tersebut dapat dilihat pada diagram berikut ini.

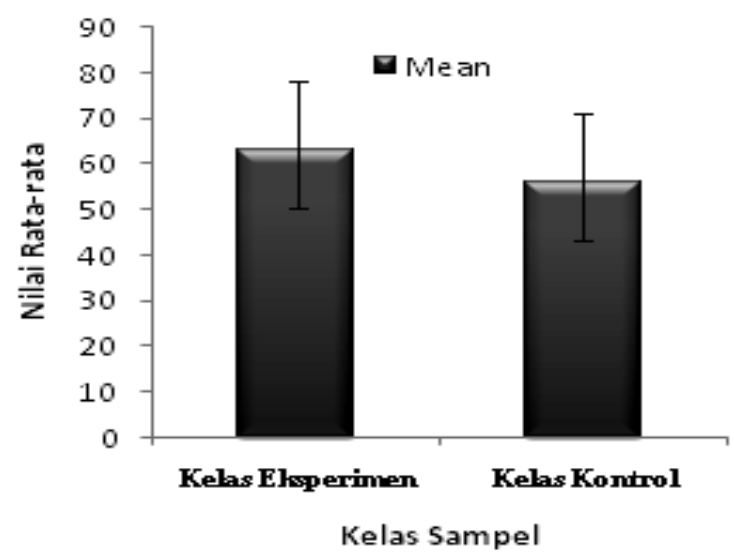

Gambar 1. Diagram nilai rata-rata hasil belajar kelas eksperimen dan kelas kontrol. Batang galat menunjukkan standar deviasi. 
Uji perbedaan post-test dianalisis menggunakan rumus t-Test: Two Sample Assuming Equal Variances pada program Microsoft Excel 2007. Secara singkat, analisis data post-test hasil belajar Biologi dapat dilihat pada tabel 1 berikut ini.

Tabel 1. Analisis data post-test hasil belajar Biologi.

\begin{tabular}{lcc}
\hline & EKSPERIMEN & KONTROL \\
\hline Mean & 62,75 & 56,17 \\
Variance & 232,98 & 162,89 \\
Observations & 23 & 20 \\
Pooled Variance & 200,50 & \\
Hypothesized & 0 & \\
Mean Difference & 41 & \\
df & 1,521 & \\
t Stat & 0,068 & \\
P(T<=t) one-tail & 1,683 & \\
t Critical one-tail & 0,136 & \\
P(T<=t) two-tail & 2,020 & \\
t Critical two-tail & \\
\hline
\end{tabular}

Berdasarkan analisis data diperoleh $t_{\text {hitung }}$ $=1,521$ lebih kecil daripada harga $t_{\text {kritik }}=2,020$, sehingga Ho diterima dan $\mathrm{Ha}$ ditolak, dengan demikian tidak ada perbedaan hasil belajar Biologi antara peserta didik yang diajarkan menggunakan metode inkuiri terbimbing dengan peserta didik yang diajar menggunakan metode ceramah bervariasi. Hal ini berarti pem-belajaran inkuiri terbimbing dan pem-belajaran ceramah bervariasi memberikan pengaruh yang sama baiknya terhadap hasil belajar Biologi peserta didik.

Hasil dalam penelitian ini tidak sesuai dengan harapan disebabkan oleh beberapa faktor. Kebiasaan pembelajaran gaya lama di dalam kelas yaitu dimana guru mendominasi dalam penyampaian materi menyebabkan peserta didik tidak terbiasa mandiri dalam belajar karena selalu ber-gantung pada gurunya. Menurut (7), peserta didik yang sudah terbiasa dengan pem-belajaran gaya lama akan kesulitan menerapkan metode inkuiri. Penelitian yang dilakukan oleh (24) membuktikan bahwa kemandirian dalam pembelajaran inkuiri dapat mempengaruhi prestasi belajar peserta didik.

Faktor yang mungkin mem-pengaruhi hasil belajar dalam penelitian ini adalah minat dan motivasi belajar peserta didik. Berdasarkan observasi dalam proses pembelajaran inkuiri, sebagian besar peserta didik bersikap apatis terhadap kerja kelompoknya, mereka cenderung diam, pasif, hanya menjadi penonton saat temantemannya yang lain bekerja. Hasil penelitian (10) menyimpulkan terdapat pengaruh yang signifikan antara motivasi belajar terhadap prestasi belajar peserta didik. Menurut penelitian (22), motivasi dalam pembelajaran inkuiri mempengaruhi hasil belajar peserta didik.

Pembelajaran inkuiri terbimbing membatasi peran guru sebagai sumber informasi, sedangkan peserta didik dituntut untuk lebih aktif dalam membangun pemahaman konsep secara mandiri. Oleh karena itu, dalam pembelajaran inkuiri terbimbing untuk materi konseptual yang berkaitan dengan hasil belajar kognitif, peserta didik difasilitasi dengan hand-out berisi materi ajar dan LDS yang dikerjakan secara berkelompok. LDS berisi pertanya-an-pertanyaan yang mengarahkan peserta didik pada konsep yang harus mereka pelajari. Diharapkan dengan menjawab pertanyaan di dalam LDS, mereka dapat menemukan dan membangun pemahaman tentang konsep-konsep tersebut secara mandiri.

Format LDS yang kurang menarik mungkin menjadi salah satu penyebab sebagian besar peserta didik kurang antusias dan kurang termotivasi dalam mengerjakan LDS di kelompoknya. LDS yang disusun hanya berisi pertanyaan-pertanyaan dengan gambar seperlunya. Mungkin jika didalam LDS terdapat permainan edukatif, maka akan dapat menarik minat dan motivasi peserta didik untuk mengerjakannya. Menurut penelitian (18), format LDS pada pokok bahasan Gerak Tumbuhan yang dipadukan dengan permainan edukatif seperti scramble, crossword puzzle dan word square membuat peserta didik lebih aktif, termotivasi, dan lebih bisa bekerja sama dalam kelompok untuk memecahkan soal di dalam LDS.

Faktor lain yang mungkin menjadi penyebab metode inkuiri terbimbing tidak berpengaruh terhadap hasil belajar peserta didik adalah kurang efektifnya penggunaan media. Pembelajaran konsep-konsep abstrak pada materi Fotosintesis dan Gerak Tumbuhan mungkin kurang tepat jika hanya mengandalkan penemuan konsep dengan membaca hand-out materi ajar sehingga pembelajaran menjadi kurang menarik. Penelitian yang dilakukan oleh (25) menunjukkan bahwa pembelajaran inkuiri terbimbing berbantuan Macromedia Flash dapat meningkatkan hasil belajar kognitif peserta didik. Penelitian yang dilakukan oleh (17) menyimpulkan bahwa penggunaan media charta pada pem-belajaran pokok bahasan Fotosintesis ber-pengaruh signifikan terhadap hasil belajar Biologi. Penelitian yang dilakukan oleh (19) menyimpulkan bahwa penggunaan media audio visual dapat meningkatkan pemahaman konsep pada pokok bahasan Fotosintesis. Penelitian yang dilakukan oleh (20) menunjukkan bahwa pembelajar-an pokok bahasan Gerak Tumbuhan dapat juga dilakukan dengan penggunaan peta pikiran (mind map). Penelitian yang dilakukan oleh (6), menyimpulkan media kartu Link and Match 
memberikan pengaruh yang lebih baik terhadap hasil belajar pada pokok bahasan Gerak Tumbuhan.

Alokasi pertemuan yang terbatas mungkin menyebabkan metode inkuiri belum menampakkan pengaruh yang signifikan dalam penelitian ini. Alokasi pertemuan untuk masing-masing materi ajar tidak lebih dari tiga kali pertemuan, dengan rincian tiga kali pertemuan untuk pokok bahasan Fotosintesis dan dua kali pertemuan untuk pokok bahasan Gerak Tumbuhan. Menurut penelitian (24), alokasi pertemuan sebanyak empat kali pada satu pokok bahasan pun masih dirasa belum cukup untuk bisa menampakkan pengaruh mtode inkuiri yang signifikan. Penyebab keterbatasan alokasi pertemuan dalam penelitian ini adalah karena alokasi pertemuan harus disesuaikan dengan program semester yang telah disusun oleh guru di sekolah, sehingga tidak memungkin kan menambah lebih banyak pertemuan untuk masing-masing pokok bahasan.

\section{Keterampilan Proses Sains}

Hasil uji perbedaan pada pre-test menunjukkan bahwa ada perbedaan ke-terampilan proses sains antara peserta didik di kelas eksperimen dengan peserta didik di kelas kontrol sebelum diberikan perlakuan, namun pada post-test kedua kelas tersebut tidak berbeda signifikan. Oleh karena itu, analisis data perlu dilanjutkan ke uji per-bedaan gain score. Gain score diperoleh dari nilai post-test dikurangi nilai pre-test. Nilai rata-rata gain score di kelas eksperimen 31,47 dan di kelas kontrol 40,38. Visualisasi nilai rata-rata gain score diperlihatkan pada diagram di bawah ini.

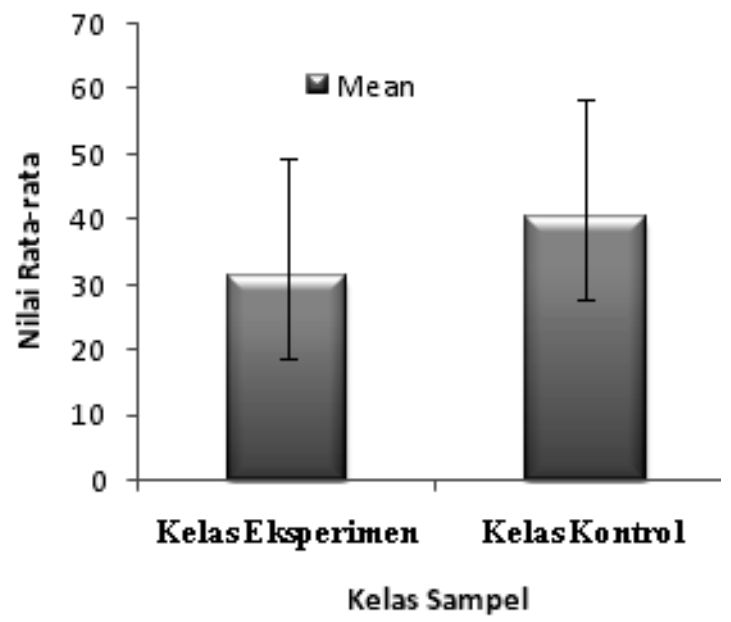

Gambar 2. Diagram nilai rata-rata gain score keterampilan proses sains kelas eksperimen dan kelas kontrol. Batang galat menunjukkan standar deviasi.

Uji perbedaan gain score dianalisis menggunakan rumus t-Test: Two Sample Assuming Equal Variances pada program Microsoft Excel 2007. Secara ringkas hasil analisis data dapat dilihat dalam tabel 2.
Tabel 2. Hasil uji hipotesis data gain score keterampilan proses sains.

\begin{tabular}{lcc}
\hline & EKSPERIMEN & KONTROL \\
\hline Mean & 31 & 40 \\
Variance & 159 & 322 \\
Observations & 22 & 18 \\
Pooled Variance & 232 & \\
Hypothesized & 0 & \\
Mean Difference & 38 & \\
df & $-1,842$ & \\
t Stat & 0,04 & \\
P(T<=t) one-tail & 1,69 \\
t Critical one-tail & 0,07 \\
P(T<=t) two-tail & 2,024 \\
t Critical two-tail & \\
\hline
\end{tabular}

Berdasarkan analisis data diperoleh $t_{\text {hitung }}$ $=1,842$ lebih kecil daripada harga $t_{\text {kritik }}=2,024$, sehingga Ho diterima dan Ha ditolak, dengan demikian tidak ada per-bedaan keterampilan proses sains antara peserta didik yang diajarkan menggunakan metode inkuiri terbimbing dengan peserta didik yang tidak diajarkan menggunakan metode inkuiri terbimbing. Hal ini berarti pembelajaran inkuiri terbimbing dan pem-belajaran ceramah bervariasi memberikan pengaruh yang sama baiknya terhadap keterampilan proses sains peserta didik.

Salah satu aktivitas yang terbanyak menampilkan keterampilan proses sains adalah aktivitas bereksperimen atau praktikum. Ini didukung oleh pendapat (2) yang menyatakan bahwa keterampilan proses sains bereksperimen merupakan proses yang meliputi seluruh proses sains dasar maupun gabungan. Metode inkuiri terbimbing memberikan kesempatan kepada peserta didik di kelas eksperimen untuk menyalurkan keterampil-an proses sains mereka, sebab pada fase mengumpulkan data, peserta didik diajak melakukan praktikum untuk memperoleh data yang dapat digunakan dalam pengujian hipotesis yang mereka rumuskan. Di kelas kontrol yang diajar menggunakan metode ceramah bervariasi juga terdapat kegiatan praktikum untuk menguatkan konsep yang telah dijelaskan, sehingga melalui praktikum peserta didik di kelas kontrol juga dapat menyalurkan keterampilan proses sains mereka. Tujuan diberikan praktikum di kelas kontrol dan kelas eksperimen adalah untuk membandingkan keterampilan proses sains dalam metode inkuiri terbimbing dengan keterampilan proses sains dalam praktikum biasa.

Temuan dalam penelitian ini ber-beda dengan temuan (1) yang menyimpul-kan bahwa ada perbedaan keterampilan proses sains antara peserta didik yang diberikan pembelajaran inkuiri terbimbing dengan peserta didik yang diberikan 
pembelajaran konvensional. Dalam penelitian (1), pembelajaran di kelas kontrol tidak terdapat praktikum melainkan hanya terjadi diskusi kelas sehingga keterampilan proses sains peserta didik tidak muncul, sedangkan peserta didik di kelas eksperimen melakukan praktikum sehingga keterampilan proses sains mereka dapat tersalurkan dan terukur. Dengan demikian jelas terlihat perbedaan keterampilan proses sains antara kelas eksperimen dan kelas kontrol.

Aspek keterampilan proses sains yang diukur oleh (1) dan yang diukur dalam penelitian juga berbeda. Penelitian (1) mengukur aspek keterampilan proses sains dasar yang meliputi observasi, klasifikasi, mengukur, memprediksi, menyimpulkan, dan mengkomunikasikan; sedangkan ke-terampilan proses sains yang diukur dalam penelitian ini terdiri dari keterampilan proses sains dasar yang meliputi meng-identifikasi variabel, mengukur, meramal-kan, dan menyimpulkan; dan keterampilan proses sains terpadu yang terdiri dari merumuskan hipotesis, mengendalikan variabel, menafsirkan data, dan bereksperimen.

Pokok bahasan yang diajarkan dalam penelitian (1) berbeda dengan yang diajarkan dalam penelitian ini (1) menerapkan pembelajaran inkuiri ter-bimbing pada pokok bahasan Sistem Peredaran Darah, sedangkan dalam penelitian ini pokok bahasan yang diajarkan adalah Fotosintesis dan Gerak Tumbuhan. Perbedaan pokok bahasan satu dengan yang lainnya menyebabkan munculnya keterampilan proses sains yang berbeda pula.

Selain faktor-faktor tersebut di atas, masih ada faktor-faktor lain yang ber-pengaruh dalam penelitian ini yang tidak diukur dan tidak dapat dikendalikan karena keterbatasan penelitian.

\section{KESIMPULAN}

Berdasarkan hasil penelitian dan pem-bahasan dapat disimpulkan: (1) metode inkuiri terbimbing dan metode ceramah bervariasi memberikan pengaruh yang sama baiknya terhadap hasil belajar Biologi pada peserta didik kelas VIII di SMPN 3 Gunungsari tahun ajaran 2013/2014; (Barba, 1998) metode inkuiri terbimbing dan metode ceramah yang divariasikan dengan praktikum memberikan pengaruh yang sama baiknya terhadap keterampilan proses sains pada peserta didik kelas VIII di SMPN 3 Gunungsari tahun ajaran 2013/2014.

\section{DAFTAR PUSTAKA}

(1) Ambarsari, W., S. Santosa, dan Maridi. 2013. Penerapan Pembelajaran Inkuiri Terbimbing Terhadap Keterampilan Proses Sains Dasar Pada Pembelajaran Biologi Siswa Kelas VIII SMP Negeri 7 Surakarta. Jurnal Pendidikan Biologi FKIP UNS Volume 5 (1): 81 - 95.
(2) Barba, R.H. 1998. Science in The Multicultural Classroom: A Guide to Teaching and Learning $2^{\text {nd }}$ Edition. Massachusetts: Allyn and Bacon A Viacom Company.

(3) Banchi, H. and R. Bell. 2008. The Many Levels of Inquiry. Journal Science and Children volume 46: 26 - 29.

(4) Bass, J. E., T. L. Contant, and A. A. Carin. 2009. Teaching Science as Inquiry $11^{\text {th }}$ Edition. Boston: Pearson/Allyn \& Bacon.

(5) Buck, L. B., S. L. Bretz., and M. H. Towns. 2008. Characterizing the Level of Inquiry in the Undergraduate Laboratory. Journal of College Science Teaching (September/October): $52-58$.

(6) Budiati, H. 2010. Perbedaan Hasil Belajar Sistem Gerak Pada Tumbuhan Menggunakan Media Permainan Link And Match dengan Pembelajaran Multi Model Pada Siswa Kelas VIII SMP Negeri 22 Surakarta. (online): http://jurnal.fkip.uns.ac.id/index.php/prosbio/a rticle/download/1284/876, Diakses 16 Juni 2014.

(7) Hanafiah, N., dan C. Suhana. 2009. Konsep Strategi Pembelajaran. Bandung: PT Refika Aditama.

(8) Handika, I. 2013. Pengaruh Pembelajaran Berbasis Masalah terhadap Penguasaan Konsep dan Keterampilan Proses Sains Siswa Kelas V Sekolah Dasar. Tesis S2. Yogyakarta: Program Pascasarjana UNY.

(9) Hansen, M. L. 2002. Defining Inquiry: Exploring The Many Types of Inquiry in The Science Classroom. The Science Teacher (February): $34-37$.

(10) Hamdu, G dan L.Agustina, 2011. Pengaruh Motivasi Belajar Siswa Terhadap Prestasi Belajar IPA di Sekolah Dasar. Jurnal Penelitian Pendidikan Volume 12 (1): 90-96.

(11) Jufri, A.W. 2013. Belajar dan Pembelajaran Sains. Bandung: Pustaka Reka Cipta.

(12) Kindsvatter, R., W. Wilen, and M. Ishler. 1996. Dynamics of Effective Teaching $3^{\text {rd }}$ Edition. New York: Longman Publishers.

(13) Kurniawan, W. dan D. Endah, H. 2008. Pembelajaran Fisika dengan Metode Inquiry Terbimbing untuk Mengembangkan Keterampilan Proses Sains. JP2F Volume 1 (2): $149-158$.

(14) Kurniawan, A.D. 2013. Metode Inkuiri Terbimbing dalam Pembuatan Media Pembelajaran Biologi untuk Meningkatkan Pemahaman Konsep dan Kreativitas Siswa SMP. Jurnal Pendidikan IPA Indonesia Volume 2 (1): 8 - 11.

(15) Martin, R., C. Sexton, K. Wagner, and J. Gerlovich. 1997. Teaching Science For All Children $2^{\text {nd }}$ Edition. Massachusetts: Allyn and Bacon A Viacom Company. 
(16) Mulyasa, E. 2010. Implementasi Kurikulum Tingkat Satuan Pendidikan: Kemandirian Guru dan Kepala Sekolah. Jakarta: Bumi Aksara.

(17) Musriatun. 2009. Pengaruh Persepsi Siswa Pada Penggunaan Media Charta dalam Pembelajaran Biologi Materi Pokok Fotosintesis Terhadap Hasil Belajar Kelas VIII di MTs. NU Nurul Huda Mangkang Kulon Semarang. Skripsi. Semarang: Fakultas Tarbiyah IAIN Walisongo.

(18) Ni'mah, L. H., Saptorini, dan S. D. Pamelasari. 2013. Pengembangan LKS IPA Terpadu Berbasis Permainan Edukatif Tema Gerak Tumbuhan dan Faktor yang Mempengaruhi untuk Siswa SMP. Unnes Science Education Journal Volume 2 (1): 149 $-156$.

(19) Patmawati, D.K.P., Ngadino, dan Karsono. 2012. Peningkatan Pemahaman Konsep Fotosintesis dengan Penggunaan Media Audio Visual. (online): http://eprints.uns. ac.id/14320/1/640-1636-1-PB.pdf., Diakses tanggal 16 Juni 2014.

(20) Rosyadi, A. T. 2011. Peningkatan Aktivitas dan Prestasi Belajar Biologi dengan Metode Mind Map Siswa Kelas VIII SMP Negeri 2 Colomadu Semester II Tahun Pelajaran 2010/2011. Skripsi. Surakarta: FKIP UMS.

(21) Sadeh, I. and M. Zion. 2011. Which Type of Inquiry Project Do High School Biology Students Prefer: Open or Guided?. Journal of Research in Science Education Volume 42 (5): $831-848$.

(22) Sutarto, Damris, M., dan Khairinal. 2011. Pengaruh Metode Inkuiri dan Motivasi Belajar Terhadap Hasil Belajar Listrik Statis dalam Pembelajaran IPA. Tekno Pedagogi Volume 1 (1): 33 - 39.

(23) Trianto. 2011. Model Pembelajaran Terpadu. Jakarta: Bumi Aksara.

(24) Untari, E. 2010. Pembelajaran Biologi Berbasis Masalah Melalui Metode Inkuiri Terbimbing dan Inkuiri Bebas Termodifikasi Ditinjau dari Kemampuan Memori dan Kemandirian Belajar. Tesis S2. Surakarta: Program Pascasarjana Universitas Sebelas Maret.

(25) Wahyudin, S. 2010. Keefektifan Pembelajaran Berbantuan Multimedia Menggunakan Metode Inkuiri Terbimbing untuk Meningkatkan Minat dan Pemahaman Siswa. Jurnal Pendidikan Fisika Indonesia Volume 6: $58-62$. 